\title{
Ecotourism Potential in Alleviating Rural Poverty: The Case of Kakum National Park in Ghana
}

\author{
By Richard Obour* \\ Paul Ankomah \\ Trent Larson ${ }^{+}$
}

\begin{abstract}
Efforts towards poverty alleviation, especially in the rural parts of Sub-Saharan Africa, have assumed critical dimensions in economic development strategies in the sub-region. Ecotourism has been identified as one such tool for addressing rural poverty. This study examines the impact of ecotourism on poverty alleviation among communities fringing Kakum National Park (KNP) in Ghana. The study objectives were: to identify ecotourism potentials in local communities; to evaluate ecotourism benefits and contributions to the local economy and to assess its impact on living standard of residents. Stratified sampling technique was employed to select households from various sections of the communities. The findings revealed that a majority of residents in the communities close to the park have benefitted from ecotourism. Specifically, ecotourism had minimized rural poverty among all the communities which had interactions with tourists. It was also noted that the communities were endowed with ecotourism potentials which if developed, could generate additional revenue.
\end{abstract}

Keywords: Ecotourism, poverty alleviation, food poverty line, developing countries, Kakum National Park

\section{Introduction}

The predominantly monocultural economies of Sub-Saharan African countries have been stagnant and under extreme stress. These stagnant economies are rapidly deteriorating due to the global instability of the prices of the subregion's export primary products. Consequently, these countries are exploring new growth models and foreign exchange generating strategies to diversify, grow and sustain their economies. Ecotourism has been identified by several of these countries as an economic development strategy with the potential to prime economic growth and help minimize widespread poverty especially in rural areas in the sub-region (Ariya and Momanyi 2015). This paper focuses on ecotourism as a strategy for addressing rural poverty in fringe communities of the Kakum National Park in Ghana and is divided into four sections. The first section reviews the literature on ecotourism. Additionally, the section provides an overview of global poverty and also explains why ecotourism is deemed appropriate for reducing rural poverty. The next section provides an overview of the study area, the study methodology, data collection and data analysis. The

\footnotetext{
${ }^{*}$ Faculty, University of Energy and Natural Resources, Ghana.

* Professor, North Carolina A\&T State University, USA.

${ }^{\dagger}$ Associate Professor, North Carolina A\&T State University, USA.
} 
third section discusses the study findings. The fourth and final section, the conclusion, summarizes the findings and provides some suggestions to enhance the ecotourism strategy to make it more effective for minimizing poverty among the communities fringing the Kakum National Park (KNP).

\section{Literature Review}

\section{Global Ecotourism Efforts}

Ecotourism is a relatively new form of tourism that is expected to minimize environmental impacts, contribute to environmental protection, enhance interaction between tourists and local people, and improve the economic and social well-being in host communities (Sirakaya et al. 1999).

The definition of the term ecotourism has undergone numerous modifications since its inception as a new form of sustainable travel. Héctor CeballosLascuráin, an expert architect from Mexico, has been credited for coining the term ecotourism in 1983. The International Ecotourism Society (TIES) (2015) defines ecotourism as "responsible travel to natural areas that conserves the environment, sustains the well-being of the local people and involves interpretation and education" (p. 1). In his analysis of ecotourism definitions, Fennel (2001) discovered 85 varied iterations. In European countries, sustainable tourism is considered a more favored term for describing ecotourism activities (Blangy and Vautier 2001). Lack of agreement regarding ecotourism's definition is common (Donohoe and Needham 2006, Orams 1995, Ross and Wall 1999, Yeo and Piper 2011) but clarifying the definition is not the focus of this paper.

Although researchers lack agreement on a universal definition, the demand for ecotourism has outpaced that of general tourism (Hultman et al. 2015, FAO 2011, Starmer-Smith 2004). Most developed countries promote some form of ecotourism; and more recently, many developing countries such as Bolivia, Belize, Mongolia, Vietnam, Bhutan, Fiji, Indonesia, and several others have also become engaged in marketing their ecotourism destinations (Honey 2008). Ecotourism programs are available to a greater or lesser degree in all continents worldwide.

In Asia, for instance, ecotourism opportunities abound in several countries such as China, Cambodia and Viet Nam. China's Qinling Mountains (near Tibet) offer many natural ecotourism resources: precipitous mountain peaks; rivers, waterfalls and geological formations; diverse forests and 56 varieties of animal species (e.g. golden monkey, nipponia nippon, takin) etc. (Dong 2011). The Qinling Mountains are also a primary source of herbal medicines and are designated as the "Chinese Medicinal Herb Storehouse" which may be of keen interest to ecotourists (Dong 2011). Ecotourism experiences such as ice and snow tours, flower tours and red leaves tours have been developed in Sichuan Province (Fang 2002) which also offers a variety of wildlife for viewing such as the giant panda (Weaver 2001). About $80 \%$ of China's protected areas include some sort of ecotourism program (Li and Han, 2001). 
In Southeast Asia, the countries of Cambodia and Vietnam are becoming known as favourable ecotourism destinations (Honey 2008). The preservation of wildlife and wilderness areas in Cambodia, a serendipitous effect of war, opens many opportunities for ecotourism development (Reimer and Walter, 2013). The Chambock area, about two hours from Phenom Penh city, offers visitors access (via ox-cart rides or other forms of non-motorized transportation) to pristine waterfalls and other natural formations within the rainforest; opportunities for birdwatching; and home-stays with locals to learn how to create traditional crafts, foods (e.g. bamboo sticky rice) and watch art performances (Lalin 2016, Ven 2015). Vietnam offers an array of ecotourism possibilities such as bird watching, agritourism-rice cultivation, shellfish harvesting; sightseeing to churches, pagodas, and marketplaces; and opportunities to learn traditional food preparation (e.g. fish sauce and rice wine) from locals (Tran and Walter 2014).

In North America, sites for ecotourism abound across the United States and include coastal beaches, urban areas, and rural locations (Honey 2008). Ecotourism pursuits such as sightseeing, outdoor (hiking, wildlife observation) and water activities (e.g. swimming, snorkeling) occur in conjunction with most trips (approximately 900,000 visits annually) to national forests, national parks, monuments, recreation areas, etc. (Honey 2008). Canada also provides a variety of ecotourism experiences including wildlife observation (polar bear, caribou, moose, grizzly bear); walking, hiking and cycling tours; heritage tours; dogsled tours/white-water canoeing, sea kayaking; guest ranch and ecolodge activities (Donohoe and Needham 2008).

Central and South America provide a rich variety of natural wonders for ecotourists. For instance, in Central America, Costa Rica is an example of one of the more advanced ecotourism destinations and offers volcano tours, canopy zip lines, bungee jumping, snorkeling, rafting and surfing (Honey 2008, Miller 2012). On the Atlantic coast of the country, the national park at Tortuguero is one of the most visited ecotourism destinations as visitors seek to access the four species of turtles that nest along beaches (CREST 2015). To protect wildlife for ecotourism, Costa Rica has enacted legislation to ban all trophy hunting within the country (CREST 2014).

A South American country known for its ecotourism is Ecuador-famous for the unique range of wildlife inhabiting the Galapagos Islands. Elsewhere in the country, ecotourism offerings include multi-day excursions into the rainforest with elements of adventure tourism (white-water rafting, canoeing and fishing for piranha) combined with visits to local villages to learn about crafts, edible plants, making bird/animal calls and experience healing rituals from local shamans (Davidov 2010). In Peru, ecotourists can experience living in the rainforest and learn about the forest ecosystem and how to preserve it as they stay at one of the lodges in the Amazonian zone of the country (Doan 2013); wildlife viewing (e.g. macaws, monkeys, giant river otters and harpy eagles) is also an important ecotourism activity (Hill and Hill 2011).

Europe is also a location for many ecotourism activities. Greece, for example, has established a profitable ecotourism market since the early 1990s and sponsors ecotourism activities such as bird-watching, canoeing, kayaking, climbing, 
mountain biking and trekking trails found in the rural and mountainous areas of the country (Spilanis and Vayanni 2004). Other ecotourism opportunities include self-guided underwater snorkeling and scuba diving routes off the south coast of Portugal (Oliveira et al. 2011); hiking through the forests and groves of Scotland to observe wildlife such as beavers in their natural habitat; following the circular scenic tourism route, the "Ring of Kerry" along the Iveragh Peninsula to encounter the beautiful lakes of Killarney; in Sweden, kayaking near the west coast in the summer and skiing, ice skating and sledding during the winter in the scenic Swedish mountains (Tourism Review Media 2016).

In Oceania, there are an abundance of ecotourism possibilities available in both Australia and New Zealand. In Northern Australia, a group of indigenous entrepreneurs has developed a range of ecotourism offerings including the viewing of wildlife such as crocodiles, a variety of birds and water buffalo and guided tours of aborigine cultural and historical sites led by indigenous experts (Fuller et al. 2015). Tourists' swimming/snorkeling with whale sharks (near Ningaloo Reef in Western Australia) and cage-diving in the Neptune Islands (South Australia) to catch up-close glimpses of Great White sharks are instances of unique ecotourism activities available (Techera and Klein 2013). Ecotourism activities in New Zealand include boat and land based whale, dolphin and seal watching and swimming (Orams 2002).

\section{Ecotourism in Sub-Saharan Africa}

The countries of Sub-Saharan-Africa offer much in the way of natural features, wildlife and cultural attractions (historical and current), the key components of ecotourism. Tanzania is a major ecotourism destination in the sub-region with four designated conservation areas or UN World Heritage Sites: the Serengeti (more wildlife per acre than anywhere on the globe); Lake Manyara, Kilimanjaro, and Ngorongoro Crater (Honey 2008). In the Ngorongoro Conservation Area, ecotourism attractions include safaris (10-12 days in duration), visits to archaeological sites of cultural interest, camping in the bush or near Maasai villages to view huts (constructed from sticks and cow dung) and observe Maasai warriors in full traditional dress perform their dances (Charnley 2005).

Local festivals are another example of ecotourism development in the subregion. In the Lamu archipelago of Kenya for instance, locals have developed festivals that attract large numbers of tourists to experience the unique blend of scenic and cultural attractions available in this remote area. Festival activities include traditional dances and ceremonies, poetry contests, displays of traditional artifacts, historical artwork, henna painting, donkey and dhow races. (Okech 2011). Tourism related activities of the festivals provide employment (parttime or seasonal) for more than 70 percent of the residents and approximately 80 percent of the community receives some type of revenue from the sale of traditional handicraft or curio (Okech 2011).

In Lesotho, the regions of Kome, Malimomg and Baroana are being developed as a rural ecotourism route in collaboration with the UNWTO and the Lesotho Tourism Development Corporation (UNWTO 2015). Activities 
include hiking, biking and pony trekking in the mountainous areas and the locals involved in these excursions receive seminar training to improve the quality of their services (e.g. tour guides/outfitters, rural homestay providers) and products (e.g. crafts sold to tourists) and to learn the best strategies for marketing these (UNWTO 2015). While ecotourism destinations are available in many countries of the sub-region, most instances appear as scattered "pockets" and are not usually pervasive within an individual country (Honey 2008).

\section{An Overview of Global Poverty}

The World Bank Group's mission “Our Dream is a World Free of Poverty" (World Bank 2016a) signifies and reinforces the importance that this body and other global organizations attach to the eradication of global poverty. In fact, Goal 1 of the 17 aspirational Goals of the United Nations Agenda for Sustainable Development is to end global poverty in all its manifestations by 2030 (https://sustainabledevelopment.un.org/sdg1). A sense of the incidence of global poverty and gross inequality may be gleaned from the fact that the GDP of the 41 HIPC (Heavily Indebted Poor Countries) is less than the wealth of 7 of the world's richest people combined (Shah 2014). To address this unfortunate cause of widespread human misery, $194 \mathrm{UN}$ member states and several civil society organizations (NGOs) not only supported the adoption of the final UN Sustainable Development document but have also agreed to implement programs and continue to undertake economic development strategies to address world poverty. According to the World Bank, considerable progress has been chalked in the efforts to reduce this global scourge. For instance, it is estimated that the percentage of the world's population living in extreme poverty (defined as less than US\$1.90 a day), fell from 12.4\% in 2012 to $10.7 \%$ in 2013 (World Bank 2016 b). In contrast, $35 \%$ of the world's population lived in extreme poverty in 1990. In absolute numbers, in 2013, 767 million people lived in extreme poverty globally compared to 881 million in 2012 and 1.85 billion in 1990 (World Bank 2016b).

However, this apparent success in reducing global poverty has not been uniform across all the world's regions. Most of the global decline in poverty from 2012-2013 occurred in East Asia and the Pacific, where the number of poor people fell by 71 million, mostly in China and Indonesia and Southeast Asia where the poverty figure fell by 37 million, mostly in India (World Bank $2016 b$ ). In contrast, the number of people living in extreme poverty in SubSaharan Africa, only fell by 4 million during the same period. This modest reduction in extreme poverty is attributable to the fact that economic gains in several of these countries, including Cameroon, Ghana, Mali and Kenya were outpaced by exponential growth in population (Beegle et al. 2016). As a result, 389 million people lived in extreme poverty in the sub-region in 2013 representing more than half the total of the extreme poor in all the other world regions combined (World Bank 2016b). In effect, half of the world's people characterized as living in extreme poverty in 2013, resided in the sub-region. Consequently, 
extreme poverty once viewed as an Asian dilemma, is now globally perceived as a sub-Saharan African problem (Vila-Artardi and Sala-i-Martin 2003).

Table 1. Number of People living in Extreme Poverty in some Countries of Sub-Saharan Africa

\begin{tabular}{|l|l|}
\hline 1. Nigeria & 86 million \\
\hline 2. Democratic Republic of Congo & 55.1 million \\
\hline 3. Tanzania & 22 million \\
\hline 4. Ethopia & 20.4 million \\
\hline 5. Madagascar & 17.9 million \\
\hline 6.Mozambique & 15.9 million \\
\hline 7. Uganda & 12.7 million \\
\hline 8. Malawi & 11.4 million \\
\hline 9. Kenya & 10.9 million \\
\hline 10. Zambia & 9.2 million \\
\hline 11. Niger & 8.6 million \\
\hline 12. Mali & 8.6 million \\
\hline 13. South Africa & 8.5 million \\
\hline 14. South Sudan & 8.1 million \\
\hline 15. Burundi & 7.9 million \\
\hline 16. Burkina Faso & 7.7 million \\
\hline 17. Rwanda & 6.7 million \\
\hline 18. Angola & 6.4 million \\
\hline 19. Cameroon & 5.8 million \\
\hline 20. Cote d' Ivoire & 5.5 million \\
\hline 21. Senegal & 5.3 million \\
\hline 22. Benin & 5.2 million \\
\hline 23. Chad & 4.6 million \\
\hline 24. Guinea & 4.3 million \\
\hline 25. Central African Republic & 3.8 million \\
\hline 26. Togo & 3.6 million \\
\hline 27. Sudan & 3.6 million \\
\hline 28. Ghana & 3.2 million \\
\hline 29. Zimbabwe & 2.6 million \\
\hline 30. Liberia & 2.3 million \\
\hline 31. Sierra Leone & 2 million \\
\hline 32. Congo & 1.6 million \\
\hline 33. Guinea Bissau & 1.2 million \\
\hline 34. Lesotho & 1.2 million \\
\hline 35. Botswana & 1.2 million \\
\hline Souce: Rose Oriz-Oso & \\
\hline
\end{tabular}

Source: Roser \& Ortiz-Ospina (2017)

The available statistics on the absolute numbers of people living in extreme poverty as of 2013 across the world's regions are as follows: Sub-Saharan Africa -389 million, Asia - 327 million, South America - 19 million, North America - 13 million, Oceania - 2.5 million, Europe - 0.7 million. According to the World Bank, reliable figures were unavailable for the Middle East and North Africa due to conflict and instability in these areas (Roser and Ortiz- 
Ospina 2017). The incidence of extreme poverty in countries in Sub-Saharan Africa is widely uneven (see Table 1). Some of the countries with the highest rates of poverty as of 2013 include: Nigeria (86 million), Democratic Republic of Congo (55.1 million), Tanzania (22 million), Ethiopia (20.4 million), Madagascar (15.9 million), Uganda (12.7 million), Mali (8.6 million) South Africa (8.5 million, Burundi (7.9 million). On the other hand, some of the countries with relatively lower rates of poverty during the same period are Botswana (1.2 million), Lesotho (1.2 million), Congo (1.6 million), Sierra Leone (2 million) and Liberia (2.3 million)(Roser and Ortiz-Ospina 2017).

The vast majority of the extreme poor people in the sub-region reside in rural areas and mostly engage in agriculture for their subsistence. Specifically, it is estimated that between $65-70 \%$ of the sub-region's population are rural residents (Beegle et al. 2016). Thus many sub-Saharan African governments consider tackling rural poverty as a viable strategy for addressing the widespread poverty responsible for the economic dislocation and stagnation in the subregion. One such tool being utilized is ecotourism (Ariya and Momanyi 2015).

Among the several factors making ecotourism a potentially effective strategy for addressing rural poverty include: it involves travel to experience and enjoy natural attractions, namely flora and fauna and relatively unadulterated cultural artefacts which are usually abundant in rural settings. Additionally, local people have intimate knowledge about flora and fauna in rural areas since they depend on these natural resources for food, fuel supply herbal medicine water, etc. As a result, rural residents are regarded as custodians not only of cultural heritage but also experts on their local ecologies and can interpret and provide information about attractions. Thus, the rural residents can receive fees for their expert knowledge of the local areas and cultures via ecotourism.

Furthermore, ecotourism does not require extensive capital outlays making it a suitable undertaking for rural communities that lack these resources. This means many rural residents can engage in ecotourism activities without the need for new high capital-intensive investments. Moreover, most ecotourists are not looking for destinations with developed infrastructure and instead prefer to travel off the beaten path. Many rural areas often lack well-developed infrastructure, and still retain most of their rustic natural characteristics. Ecotourism also does not require any special skills, expertise or training and can become another means of financial support and sustenance for rural people who have very little if any education. This characteristic of ecotourism makes it conducive for absorbing large segments of unemployed and underemployed rural residents into more productive segments of society. However, it is worth mentioning that current evidence of the ecotourism benefits in established global ecotourism destinations appear to be mixed (Archibald and Naughton-Tres 2001, Jing and Fucai 2011, Suntikul and Ugyen 2016, Waylen et al. 2009). 


\section{Materials and Methods}

\section{Study Area}

The Kakum National Park (KNP) has become a popular destination for ecotourists who seek not only adventure, but also an opportunity to learn more about rainforest ecology and culture and to contribute to conservation efforts and improve the well-being of the local people. Clearly, if the Central region is the hub of tourism in Ghana, KNP is the leading ecodestination in southern Ghana (Akyeampong 2011). KNP bestrides three political districts in the Twifo Hemang Lower Denkyira, Abura-Asebu-Kwamankese and Assin South Districts.

Kakum National Park is located in the Central Region of Ghana and it is three (3) hours drive from Accra, the national capital and thirty (30) minutes drive from Cape Coast, the regional capital. The park consists of two blocks of forest lying adjacent to each other; Kakum National Park and the Assin Attandanso Resource Reserve which cover $210 \mathrm{~km}^{2}$ and $150 \mathrm{~km}^{2}$ respectively of tropical rainforest and a high faunal diversity. The reserves lie between longitudes $1^{\circ} 51^{\prime}$ and $1^{\circ} 30^{\prime} \mathrm{W}$ and latitudes $5^{\circ} 20^{\prime}$ and $5^{\circ} 40^{\prime} \mathrm{N}$ (KNP Management Plan 1996).

The park is surrounded by an estimated population of 45,000 people made up of 27 villages and over 400 hamlets within the first $5 \mathrm{~km}$ from the park boundary (KNP Management Plan, 1996). Both subsistence and commercial types of agriculture are the predominant activities in the communities surrounding KNP. The family serves as the basic labor force, however, within the Assin District hired labor accounts for 52\% of the total labor force (KNP Management Plan 1996).

The major food crops cultivated by the local people include plantain, cassava, maize, yam, cocoyam, rice and vegetables. Cash crops are cocoa, oil palm, coffee, citrus and coconut. The average farm size for households is about 10 acres, with $85 \%$ of households cultivating less than 16 acres. Farming is an all year-round activity (KNP Management Plan 1996). As economic conditions in most rural settings have become more difficult, women are increasingly setting up their own farms. A field survey in 1992 revealed that about $32 \%$ of the women in the Assin District had average farm sizes of 5-8 acres (KNP Management Plan 1996). The lack of good roads and motorized means of transport has resulted in head-porting of farm produce by women to the nearest marketing centers. As a result, the women are only able to sell just enough to purchase basic household needs (KNP Management Plan 1996).

In many communities around KNP, livestock raising is a common feature as a supplementary source of income. Small scale sheep and goat rearing is mostly done for commercial purposes. Domestic fowls are kept as supplementary protein source, even though they are sold in times of financial difficulty (KNP Management Plan 1996). Distillation of local alcoholic drink (Akpeteshie) serves as a secondary economic activity for some people in the local communities. Apart from the production of palm oil in the well-established oil palm plantations, small scale palm oil milling is carried out mostly by women to supplement 
household incomes. Other activities in the communities include preparation of food for sale (especially, kenkey and gari), basketry and wild honey hunting (KNP Management Plan 1996). Hunting is one of the off farming activities undertaken by the local people. There are however a number of indigenous people who hunt as their primary source of income (KNP Management Plan 1996).

\section{Data Collection}

The data for the study were gathered from September 2011 to April 2012 using primary sources which included questionnaire administration and personal interviews with various stakeholders. The respondents included the staff of the Ghana Wildlife Division, Ghana Heritage Conservation Trust (GHCT), traditional and opinion leaders, district assembly representatives and local residents. Personal observations were also made at the visitors centre, park headquarters and of the interactions between tourists and the community members. Three communities were selected for the research out of which, two were purposively selected. The major settlement and gateway to the KNP, Abrafo-Odumasi and Mesomagor, were purposively selected to be used as a pilot case because they were the only communities around KNP where tourist visits and ecotourism activities were concentrated. The third community called Antwikwaa was randomly selected.

Table 2. Sample Size of the Communities

\begin{tabular}{lcc}
\hline Community & Estimated number of households & Respondents sampled \\
\hline Abrafo-Odumasi & 520 & 52 \\
Antwikwaa & 217 & 21 \\
Mesomagor & 220 & 22 \\
Total & 957 & 95 \\
\hline
\end{tabular}

Ten percent $(10 \%)$ of the total households in each community were sampled randomly using the stratified random technique. Questionnaires were administered to one household member per house. Respondents selected were any mature member of the household but preference was given to the head of the household. A total of ninety-five (95) locals were selected from AbrafoOdumasi (52), Antwikwaa (21) and Mesomagor (22) and interviewed (Table 2).

\section{Data Analysis}

The data obtained were coded using Statistical Package for the Social Sciences (SPSS), employing both descriptive (such as frequencies, means, percentages and proportions) and inferential statistical tools. The Progress out of Poverty Index ${ }^{\mathrm{TM}}$ (PPI ${ }^{\mathrm{TM}}$ ) for Ghana which is a tool that measures poverty level of groups and individuals was used to assess the poverty level of the three communities namely, Abrafo-Odumasi, Antwikwaa and Mesomagor. "The CGAP [Consultative Group to Assist the Poor], Grameen Foundation and the Ford Foundation endorse the use of rigorous poverty assessment tools and believe the Progress out of Poverty Index ${ }^{\mathrm{TM}}$ (PPI) is a highly effective tool for those 
institutions interested in measuring the likelihood of client poverty" (Haq and Farooqi 2009: 2). While the PPI is built on a universal methodology, the PPI used in this study is specifically based on Ghana's nationally representative household income and expenditure survey. It estimates the likelihood that a respondent has income below the National Poverty Line, National Food Line. The total points scored from respondents' PPI to a poverty level is estimated using a practical list of ten indicators (e.g. number of household members, highest level of education attained by male or female head of household, and the head of household's main type of employment in agriculture). Each indicator had a score that reflected client response, and all ten indicators received a total score. The indicators in the PPI were based on data from the 2005-2006 Ghana Living Standards Survey (GLSS) conducted by the Ghana Statistical Service (GSS). This was the best and most recent survey on household income and expenditure data available at the time of the study and individuals were ranked according to the applicable poverty line.

Table 3. Gender of the Communities

\begin{tabular}{llcc}
\hline Community & Gender & Respondents & Percentage (\%) \\
\hline Abrafo-Odumasi & Male & 30 & 32 \\
& Female & 22 & 23 \\
Antwikwaa & Male & 16 & 17 \\
& Female & 5 & 5 \\
Mesomagor & Male & 14 & 15 \\
& Female & 8 & 8 \\
Total & & $\mathbf{9 5}$ & $\mathbf{1 0 0}$
\end{tabular}

Table 4. Occupation of Respondents

\begin{tabular}{llcc}
\hline Community & Occupation & Respondents & Percentage (\%) \\
\hline \multirow{3}{*}{ Abrafo-Odumasi } & Farming & 27 & 28 \\
& Civil service & 12 & 13 \\
& Petty trading & 10 & 11 \\
Antwikwaa & Artisanship & 3 & 3 \\
& Farming & 17 & 18 \\
& Civil service & 1 & 1 \\
Mesomagor & Petty trading & 2 & 2 \\
& Artisanship & 1 & 1 \\
& Farming & 16 & 17 \\
& Civil service & 3 & 3 \\
& Petty trading & 2 & 2 \\
& Artisanship & 1 & 1 \\
\hline
\end{tabular}


Table 5. Level of Education

\begin{tabular}{llrr}
\hline Community & Level of education & Respondents & Percentage (\%) \\
\hline Abrafo-Odumasi & No education & 13 & 14 \\
& Primary & 9 & 10 \\
& JSS & 19 & 20 \\
& GCE/SSS & 3 & 3 \\
& Technical & 2 & 2 \\
Antwikwaa & Tertiary & 6 & 6 \\
& No education & 12 & 13 \\
& Primary & 4 & 4 \\
& JSS & 4 & 4 \\
& GCE/SSS & 1 & 1 \\
Mesomagor & Technical & 0 & 0 \\
& Tertiary & 0 & 0 \\
& No education & 10 & 11 \\
& Primary & 2 & 2 \\
& JSS & 7 & 7 \\
& GCE/SSS & 0 & 0 \\
& Technical & 1 & 1 \\
& Tertiary & 2 & 2 \\
& & $\mathbf{9 5}$ & $\mathbf{1 0 0}$ \\
\hline
\end{tabular}

\section{Results and Discussion}

A total of ninety-five (95) local people responded to the questionnaires administered with a greater proportion of the respondents coming from AbrafoOdumasi (52) representing 55\%, followed by Mesomagor (22) representing $23 \%$ and Antwikwaa (21) community representing $22 \%$. A higher number of respondents was chosen from Abrafo-Odumasi because it was the largest of the three communities. Out of the 95 questionnaires issued in the communities, 60 were male representing the majority of the respondents and 35 were female. Table 3 shows the gender breakdown for each community.

Table 6. Direct Benefits of Ecotourism to the Community as Identified by Respondents

\begin{tabular}{llc}
\hline Community & Ecotourism Benefits Identified & Respondents \\
\hline Abrafo-Odumasi & ICT center & 10 \\
& Market & 23 \\
& Boreholes & 6 \\
& Community social center & 24 \\
& Community library & 18 \\
& Teachers quarters & 20 \\
Antwikwaa & School building & 16 \\
& School building & 12 \\
Mesomagor & Loans & 2 \\
& School building & 12 \\
& Boreholes & 9 \\
& Community center & 10
\end{tabular}


Figure 1. Map of Ghana showing KNP and selected Communities

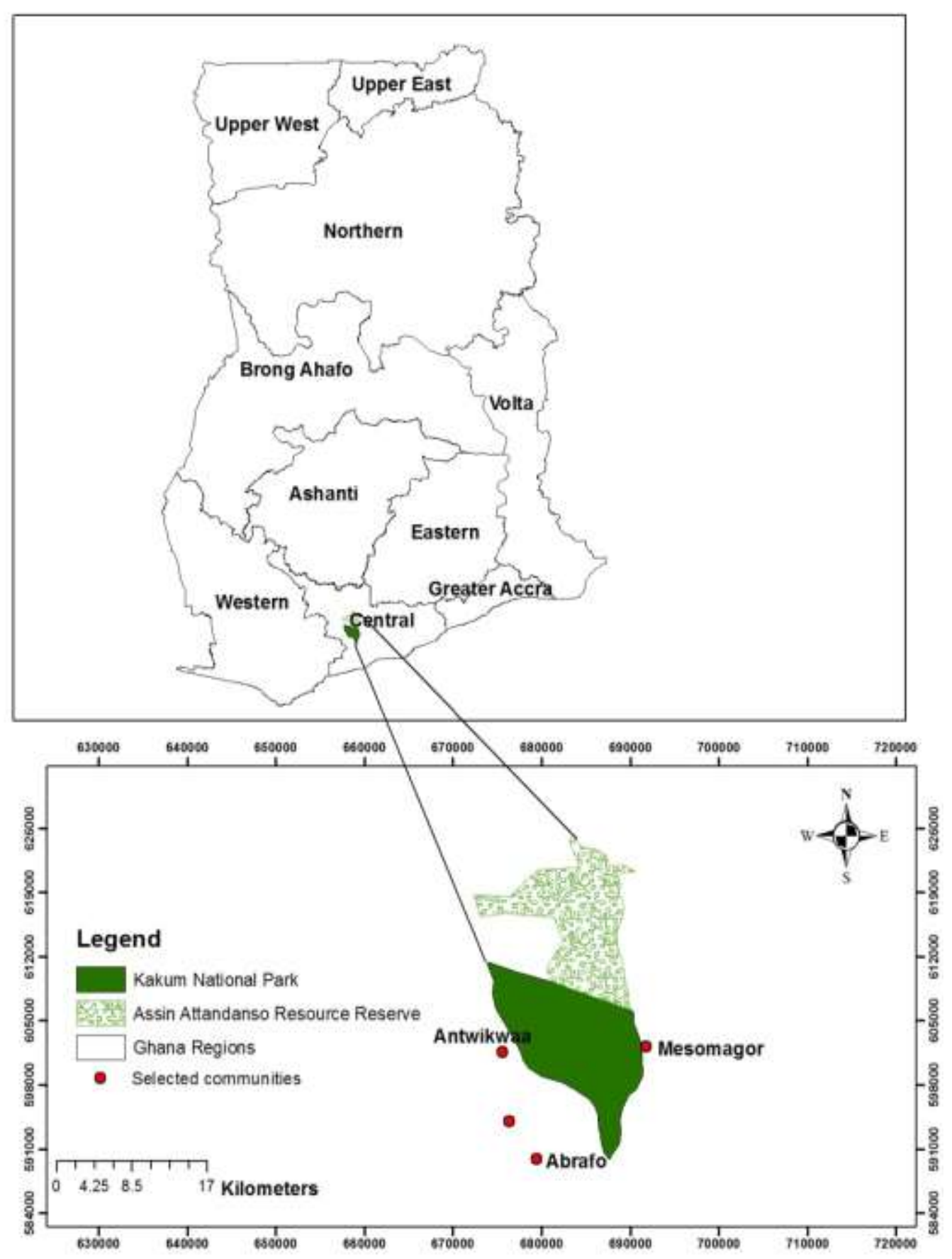

The main occupation in the three communities was farming. The remainder of the respondents were involved in non-farming occupations such as civil service $(17 \%)$, petty trading $(15 \%)$ and artisanship (5\%). The specific breakdown of occupations in each community is shown in Table 4. A majority of the rural people surveyed had very little education. For a summary of the educational attainment by community see Table 5 . The respondents also indicated that 
ecotourism contributed to the local economies as well as enhanced development in these communities (see Table 6 and Figure 1). Specifically, benefits included the construction of an ICT center, market facilities, boreholes, school buildings, community social center, community library, teachers' quarters, and availability of small business loan programs.

\section{The Poverty Level of the Local Community}

Poverty as initially defined as people living on less than US $\$ 1$ a day by the World Bank (UN 2009) is determined by a number of factors such as geographical location of community, education level, gender, household's sizes, infrastructure, employment and income level of the rural people. From the above list of factors, geographical location was the critical factor examined in the study to verify its impact, if any on poverty in the three communities. Consequently, the study does not make any inference of the impact of the other factors on poverty in these communities.

Table 7. Poverty Level of the Local Communities

\begin{tabular}{|c|c|c|c|c|c|}
\hline Community & Respondents & $\begin{array}{c}\text { Total } \\
\text { below } \\
\text { National } \\
\text { poverty } \\
\text { line }\end{array}$ & $\begin{array}{c}\text { Total } \\
\text { above } \\
\text { National } \\
\text { poverty } \\
\text { line }\end{array}$ & $\begin{array}{c}\text { Total } \\
\text { below } \\
\text { National } \\
\text { food } \\
\text { security } \\
\text { line }\end{array}$ & $\begin{array}{c}\text { Total } \\
\text { above } \\
\text { National } \\
\text { food } \\
\text { security } \\
\text { line }\end{array}$ \\
\hline $\begin{array}{c}\text { Abrafo- } \\
\text { Odumasi }\end{array}$ & 52 & $11 \%$ & $89 \%$ & $5 \%$ & $95 \%$ \\
\hline Antwikwaa & 21 & $53 \%$ & $47 \%$ & $37 \%$ & $63 \%$ \\
\hline Mesomagor & 22 & $40 \%$ & $60 \%$ & $22 \%$ & $78 \%$ \\
\hline
\end{tabular}

The data analysis revealed that geographical location was one factor that contributed to poverty in the study area. The most popular community fringing the park, Abrafo-Odumasi was also the least poverty-stricken community. It is the gate way to the park. Mesomagor which had a developed community based ecotourism was second least poverty-stricken. Antwikwaa, the most povertystricken community was not well known due to its remoteness and had no ecotourism activities developed (see Figure 1). Research conducted by Canagarajah et al. (1998) in Ghana showed that location of a community in Ghana relative to centers of economic activities was an important factor in determining poverty in particular communities.

Table 7 indicates community, number of respondents, total below and above the national poverty line and the total below and above the national food poverty line. Out of the total number of 52 local people interviewed in Abrafo-Odumasi $11 \%$ of the respondents lived below the national poverty line and $89 \%$ above 
the national poverty line. The corresponding figures for the national food poverty line indicates a total of $5 \%$ of Ghanaians lived below the national food poverty line and $95 \%$ above the national food poverty line. In Mesomagor, out of 22 respondents interviewed $40 \%$ lived below the national poverty line and $60 \%$ above the national poverty line. In Antwikwaa community, 21 local people were interviewed out of which $53 \%$ lived below the national poverty line and $47 \%$ above the national poverty line while $37 \%$ lived below the national food poverty line and $63 \%$ of the respondents were above the national food poverty line.

\section{Ecotourism Potentials identified in the Communities}

Respondents identified several ecotourism potentials in their communities (see Table 8). These included unique rocks, home stay opportunities, bamboo orchestra, locally-brewed alcoholic beverage, farm tours, culture of the people which includes cooking, washing, etc. Personal observations also identified potential ecotourism attraction such as basket weaving, traditional soap making, palm oil extraction and traditional festivals celebrated in the communities.

According to the management of KNP, most ecotourists who visit KNP usually express interest in visiting other communities around the park to experience traditional rural life. However, due to the rudimentary nature of the rural roads and undeveloped eco-sites within these communities it has not been feasible to encourage such visitations. This observation would seem to suggest that if other ecotourism activities were developed and supported within the community around the park, they could attract ecotourists visiting the main attraction in KNP (the famous canopy walkway) and generate additional revenues to improve the living standards of the local communities (per com, 2011).

Table 8. Ecotourism Potentials identified in the Communities

\begin{tabular}{llcc}
\hline Community & Ecotourism potentials & Respondents & Percentage (\%) \\
\hline Abrafo-Odumasi & Farm tour & 2 & 19 \\
& Local brewed alcohol & 1 & 3 \\
& Cultural attractions & & \\
& (cooking, washing, etc.) & 4 & 11 \\
\multirow{3}{*}{ Antwikwaa } & Homestay & 7 & 5 \\
& Unique rocks & 2 & 5 \\
Mesomagor & Farm tour & 1 & 3 \\
& Bamboo orchestra & 17 & 46 \\
Total & Homestay & 3 & 8 \\
\hline
\end{tabular}

However, in Mesomagor, there was an operation of an Eco-village. This community-based ecotourism was developed by Conservation International (CI) during the establishment of the KNP. It was to be used as a case study of alternative source of revenue for the community, a way for improving the wellbeing of the local people. As part of the project's implementation, the residents 
revived a bamboo orchestra that had existed in the community in the 1970s and now entertains tourists for a fee. The orchestra uses only musical instruments made from the bamboo tree and serves as a source of employment in the community. Furthermore, with permission from park officials, the villagers have also created hiking trails to one of the largest trees in the forest locally called "baaku" (Tieghemelia Heckelli), the seeds of this tree attract wild animals like duiker and elephants. A platform has been erected under this tree, and for a fee ecotourists can mount it to watch these wild animals (Personal communication 2011).

\section{Limitations of the Study}

Several challenges were encountered during the data collection stage which could have influenced responses to survey questions. These challenges were:

i. There was some degree of difficulty in providing concise and comprehensive translation of certain technical words that could be understood easily by respondents in their native language.

ii. Respondents exhibited antagonism stemming from their dissatisfaction with the development of tourism which they perceived as denying them the opportunity to enhance their living standards. They overtly expressed this anger by either refusing to respond to some of the questions or in some cases issued warnings to staff of KNP and researchers to refrain from visiting their communities.

\section{Conclusions}

The study revealed that ecotourism had significantly contributed to alleviating rural poverty especially where the tourist directly interacted with the locals. Specifically, 11\% (Abrafo-Odumasi), 53\% (Antwikwaa), and 40\% (Mesomagor) of the respondents lived below the national poverty line while $89 \%, 47 \%$ and $60 \%$ lived above the national poverty line (US \$1 per day) in Abrafo-Odumasi, Antwikwaa and Mesomagor respectively. The study also suggested that 5\%, $37 \%$ and $23 \%$ of the local people lived below the national food poverty line while $95 \%, 63 \%$ and $78 \%$ lived above the national food poverty line in AbrafoOdumasi, Antwikwaa and Mesomagor community respectively.

It was also discovered in this study that the communities were endowed with numerous ecotourism potentials which if developed could improve the living standard of the locals, enhance general economic development and lessen rural poverty. A number of ecotourism potentials including unique rocks, home stay opportunities, bamboo orchestra, locally-brewed alcoholic beverages, farm tours, culture of the people which include cooking, washing were identified in the communities. Personal observation also listed basket weaving, traditional soap making, palm oil extraction and traditional festivals as additional ecotourism attractions with untapped potentials. 
To positively impact poverty alleviation in the communities fringing the park, several strategies are suggested. Among these are: implementing training regimes to provide community members interested in engaging in tourism activities the necessary skills and know-how to add value to their ecotourist offerings. Training could also involve facilitating use of technology, social media, internet, etc. The communities could also be organized into cooperative units to enhance their effectiveness in marketing, small loan acquisitions, strengthen their bargaining positions with KNP management, etc. The cooperative units could also help in the development of cultural attractions and other local traditions that could supplement the wildlife attractions of KNP. Lastly, KNP management could empower local residents by including community opinion leaders in the KNP decision-making process and make these communities stakeholders in the local ecotourism economy. Such a development is likely to minimize any antagonistic attitudes these communities have towards potential tourists visiting KNP.

\section{Acknowledgement}

Our thanks to the Wildlife Division of the Forestry Commission, the management and staff of KNP, the Park Manager, Mr. Danel Ewur; the Law Enforcement Officer, Mr. Riverson; Tourism Officer, Mr. Matthew; Community Relation Officer, Ernestina Anie and the Site Manager of GHCT, Mr L.K. Brobbey; the junior staff including the rangers, wildlife guards, tour guides and drivers for taking care of our team and providing useful ideas and information.

\section{References}

Akyeampong O (2011) Pro-poor tourism: Residents' expectations, experiences and preceptions in the Kakum National Park Area in Ghana. Journal of Sustainable Tourism 19(2): 197-213.

Archibald K, Naughton-Treves L (2001) Tourism revenue-sharing around national parks in Western Uganda: Early efforts to identify and reward local communities. Environmental Conservation 28(2): 135-149.

Ariya G, Momanyi S (2015) Contribution of gold-decorated lodges to poverty reduction among local residents in Maasai Mara and Amboseli Protected Areas, Kenya. Journal of Tourism Hospitality 4. Doi =http://doi.acm.org/10.4172/2167 0269.1000172.

Beegle K, Christiaensen L, Dabalen A, Gaddis I (2016) Poverty in a rising Africa. Washington, D.C.: World Bank. Doi =http://doi.acm.org/10.596/987-1-4648-0723-7.

Blangy S, Vautier S (2001) Europe. In D Weaver (ed) Encyclopedia of ecotourism, 155-171. New York, NY: CABI Publishing.

Canagarajah S, Mazumdar D, Ye X (1998) The structure and determinants of inequality and poverty reduction in Ghana, 1988-92 (Working Paper). Retrieved from http: //documents.worldbank.org/curated/en/357261468771078875/pdf/multi-page.pdf. [Accessed 15 April 2017]. 
CREST (2014) Economic impact of bear viewing and bear hunting in the Great Bear Rainforest of British Columbia. Washington, D.C.: Center for Responsible Travel. Retrieved from http://www.responsibletravel.org/projects/documents/Economic_Im pact_of_Bear_Viewing_and_Bear_Hunting_in_GBR_of_BC.pdf. [Accessed 27 September 2017].

CREST (2015) The case for responsible travel: Trends \& statistics 2015. Washington, DC: Center for Responsible Travel. Retrieved from http://www.responsibletrav el.org/resources/documents/2015\%20Trends\%20\&\%20Statistics_Final.pdf. [Accessed 27 September 2017].

Charnley S (2005) From nature tourism to ecotourism? The case of the Ngorongoro Conservation Area, Tanzania. Human Organization 64(1): 75-88.

Davidov V (2010). Shamans and shams: The discursive effects of ethnotourism in Ecuador. The Journal of Latin American and Caribbean Anthropology 15(2): 387410.

Doan T (2013) Sustainable ecotourism in Amazonia: Evaluation of six sites in Southeastern Peru. International Journal of Tourism Research 15: 261-271.

Dong H (2011) Ecotourism in the Northern Piedmont in the Oineing Mountains. In Jaime Sabe (ed.), Ecotourism and sustainable tourism: New perspectives and studies. New York, NY: CRC Press.

Donohoe H, Needham R (2006) Ecotourism: The evolving contemporary definition. Journal of Ecotourism, 5(3): 192-210.

Donohoe H, Needham R (2008) Internet-based ecotourism marketing: Evaluating Canadian sensitivity to ecotourism tenets. Journal of Ecotourism 7(1): 15-43.

Fang Y (2002) Ecotourism in Western Sichuan, China. Mountain Research and Development 22(2): 113-115.

FAO (2011) Ecotourism can play vital role in maintaining healthy forests. Retrieved from http://www.fao.org/news/story/en/item/90192/icode/. [Accessed 15 March 2017].

Fennel D (2001) A content analysis of ecotourism definitions. Current Issues in Tourism, 4 (5): 403-421.

Fuller D, Buultjens J, Cummings E (2015) Ecotourism and indigenous micro-enterprise formation in Northern Australia opportunities and constraints. Tourism Management 26: 891-904.

Haq A, Farooqi M (2009) Poverty profile of microfinance clients in Pakistan: Evidence from four MFPs using the Poverty Scorecard. Pakistan Microfinance Network. Retrieved from http://www.microfinanceconnect.info/assets/articles/MicroNOTE $\% 207 \% 20 \% 20$ Poverty\%20Profile\%20MF\%20Clients\%20in\%20Pakistan.pdf. [Accessed 22 March 2017].

Hill J, Hill R (2011) Ecotourism in Amazonian Peru: Uniting tourism, conservation and community development. Geography $96,75-85$.

Honey M (2008) Ecotourism and Sustainable Development: Who Owns Paradise? $\left(2^{\text {nd }}\right.$ ed.). Washington, DC: Island Press.

Hultman M, Kazeminia A, Ghasemi V (2015) Intention to visit and willingness to pay premium for ecotourism: The impact of attitude, materialism, and motivation. Journal of Business Research 68: 1854-1861.

Jing Y, Fucai H (2011) Research on management of ecotourism based on economic models. EnergyProcedia 5: 1563-1567.

Kakum National Park (KNP) Management Plan (1996) Kakum National Park and Assin Attandanso Resource Reserves, Management Plan. Ghana: Wildlife Department.

Lalin D (2016) A success story: Chambok community-based ecotourism. Khmer Times. Retrieved from http://www.khmertimeskh.com/news/19491/a-success-story-cham bok-community-based-ecotourism. [Accessed 14 March 2017]. 
Li W, Han N (2001) Ecotourism management in China's nature reserves. Ambio 30: 6263.

Miller A (2012) Ecotourism development in Costa Rica: The search for Oro Verde. New York: Lexington Books.

Okech R (2011) Promoting sustainable festival events tourism: A case study of Lamu Kenya. Worldwide Hospitality and Tourism Themes 3(3): 193-202.

Oliveira M, Pita C, Gonclaves J, Leite L, Costa C, Erzini K (2011) Ecotourism snorkelling routes at Marinha Beach (Algarve). In A Micallef (ed) MCRR3-2010 Conference Proceedings, Journal of Coastal Research, Special Issue, No. 61, 274-281. Grosseto, Tuscany, Italy. ISSN 0749-0208.

Orams M (1995) Towards a more desirable form of ecotourism. Tourism Management 16(1): 3-8.

Orams M (2002) Marine ecotourism as a potential agent for sustainable development in Kaikoura, New Zealand. International Journal of Sustainable Development 5(3): 338-352.

Reimer K, Walter P (2013) How do you know it when you see it? Community-based ecotourismin the Cardamom Mountains of southwestern Cambodia. Tourism Management 34: 122-132.

Roser M, Ortiz-Ospina E (2017) Global extreme poverty. Published online at OurWorldIn Data.org. Retrieved from https://ourworldindata.org/extreme-poverty. [Accessed 28 September 2017].

Ross S, Wall G (1999) Ecotourism: Towards congruence between theory and practice. Tourism Management 20: 123-132.

Shah A (2014) Causes of poverty. Retrieved from http://www.globalissues.org/issue/ 2/causes-of-poverty. [Accessed 28 September 2017].

Sirakaya E, Sasidharan V, Sönmez S (1999) Redefining ecotourism: The need for a supply-side view. Journal of Travel Research 38(2):168-172.

Spilanis I, Vayanni H (2004) Sustainable tourism: Utopia or necessity? The role of new forms of tourism in the Aegean Islands. In B Bramwell (ed) Coastal mass tourism: diversification and sustainable development in Southern Europe, 269291. Clevedon, UK: Channel View Publications.

Starmer-Smith C (2004) Eco-friendly tourism on the rise. Retrieved from http:// www. telegraph.co.uk/travel/731611/Eco-friendly-tourism-on-the-rise.html [Accessed 23 February 2017].

Suntikul W, Ugyen D (2016) Tourism development: The challenges of achieving sustainable livelihoods in Bhutan's remote reaches. International Journal of Tourism Research 18: 447-457.

Techera E, Klein N (2013) The role of law in shark-based eco-tourism: Lessons from Australia. Marine Policy 39: 21-28.

The International Ecotourism Society (2015) TIES Announces Ecotourism Principles Revision. Retrieved from http://www.ecotourism.org/news/ties-announces-eco tourism-principles-revision. [Accessed 23 February 2017].

Tourism Review Media (2016) Top 5 European destinations perfect for ecotourism. Retrieved from http://www.tourism-review.com/five-ecotourism-european-desti nations-news5036. [Accessed 21 January 2017].

Tran L, Walter P (2014) Ecotourism, gender and development in northern Vietnam. Annals of Tourism Research 44: 116-130.

UN (2009) Rethinking poverty: Report on the world social situation 2010. New York, NY: United Nations. Retrieved from http://www.un.org/esa/socdev/rwss/docs/20 10/fullreport.pdf. [Accessed 28 September 2017]. 
UNWTO (2015) ST-EP project in Lesotho delivers training seminars for excursion providers, tour guides, home stay providers and crafters. Retrieved from http:// bit.ly/2AJUP22. [Accessed 14 January 2017].

Ven S (2015) Host residents' attitude toward community-based ecotourism: Empirical study in Southwestern Cambodia. Journal of Tourism Hospitality 4: 140-151.

Vila-Artadi E, Sala-i-Martin X (2003) The economic tragedy of the Xxth Century: Growth in Africa. NBER (Working Paper). Retrieved from https://ssrn.com/abs tract $=425601$. [Accessed 28 September 2017].

Waylen K, McGowan P, Pawi Study Group, Milner-Gulland E (2009) Ecotourism positively affects awareness and attitudes but not conservation behaviors: A case study of Grande Riviere, Trinidad. Oryx 43(3): 343-351.

Weaver D (2001) Ecotourism. Sydney, Australia: John Wiley \& Sons.

World Bank (2016a) Overview. Retrieved from http://www/worldbank.org/en/topic/ Poverty. [Accessed 14 April 2017].

World Bank (2016b) Poverty and Shared Prosperity 2016: Taking on Inequality. Washington, DC: World Bank. http://.doi.asm.org/10.1596/978-1-4648-0958-3. License: Creative Commons Attribution CC BY 3.0 IGO.

Yeo M, Piper L (2011) The ethics and politics of defining ecotourism: Not just an academic question. International Journal of Humanities and Social Science 1(8): $11-18$. 
